\title{
Comparative analysis of the leaf anatomy in two Parodiolyra species (Poaceae: Olyreae) occurring on forests in Eastern Brazil
}

\author{
Jesus Junior, LA. ${ }^{a *}$, Oliveira, RP. ${ }^{a, b}$, Leite, KRB. ${ }^{a}$ and Silva, LB. ${ }^{a}$ \\ aDepartamento de Botânica, Instituto de Biologia, Universidade Federal da Bahia - UFBA, \\ Rua Barão de Geremoabo, 147, Campus de Ondina, CEP 40170-290, Salvador, BA, Brazil

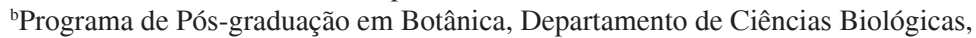 \\ Universidade Estadual de Feira de Santana - UEFS, BR 116N, Km 3, CEP 44031-460, Feira de Santana, BA, Brazil \\ *e-mail: salsaluiz@ hotmail.com \\ Received January 18, 2011 - Accepted June 7, 2011- Distributed February 29, 2012
}

(With 21 figures)

\begin{abstract}
Parodiolyra is a member of Olyreae, a tribe of herbaceous bamboo species within the Poaceae. The genus has five species, four of which were previously regarded as belonging to Olyra L. Parodiolyra has a Neotropical distribution and only two species occur on forests in Eastern Brazil: P. micrantha (Kunth) Zuloaga \& Davidse and P. ramosissima (Trin.) Soderstr. \& Zuloaga, the first widely distributed in the Neotropics while the second is endemic to the state of Bahia. Leaf anatomy of the two species was analysed with the aid of an optical microscope. The objective was to describe the microscopic characters and evaluate if they can be useful for the taxonomy of the genus. The observed anatomical structures did not differ from other genera of herbaceous bamboos, however some characters, both from the mesophyll and the epidermis, were useful to delimit the two species.
\end{abstract}

Keywords: bambusoideae, microscopic characters, herbaceous bamboos, specific delimitation.

\section{Análise comparativa da anatomia foliar de duas espécies de Parodiolyra Soderstr. \& Zuloaga (Poaceae: Olyreae) ocorrentes em florestas do leste do Brasil}

\section{Resumo}

Parodiolyra está inserido em Olyreae, tribo de bambus herbáceos pertencente à Poaceae, e apresenta cinco espécies, sendo quatro delas previamente consideradas como parte de Olyra $L$. O gênero tem distribuição neotropical e apenas duas espécies ocorrem nas florestas do leste do Brasil: P. micrantha (Kunth) Zuloaga \& Davidse e P. ramosissima (Trin.) Soderstr. \& Zuloaga; a primeira, amplamente distribuída no Neotrópico, e a última, endêmica do Estado da Bahia. A anatomia foliar dessas duas espécies foi analisada através de microscopia de luz, com o objetivo de descrever seus caracteres microscópicos e avaliar se os mesmos podem ser úteis para a taxonomia do gênero. A estrutura anatômica observada não se diferencia daquela dos demais gêneros de bambus herbáceos, mas alguns caracteres do mesofilo e da epiderme foram úteis para delimitar as duas espécies.

Palavras-chave: bambusoideae, caracteres microscópicos, bambus herbaceous, delimitação específica.

\section{Introduction}

Parodiolyra Soderstr. \& Zuloaga is a genus of herbaceous bamboos belonging to Poaceae, Bambusoideae. The genus is included in Olyreae, and has a wide distribution in the Neotropical region, ranging from Costa Rica to Bolivia, Paraguay, Northeastern Argentina and Brazil (Oliveira and Longhi-Wagner, 2001). Parodiolyra comprises five species, and until recently four of these species were placed in Olyra L. However, macromorphological characters, especially reproductive ones, were used by Soderstrom and Zuloaga (1989) to justify the segregation of these species into Parodiolyra.

The four species formerly placed in the genus are Parodiolyra micrantha (Kunth) Zuloaga \& Davidse,
P. ramosissima (Trin.) Soderstr. \& Zuloaga, P. lateralis (J. Presl ex Nees) Soderstr. \& Zuloaga and P. luetzelburgii (Pilg.) Soderstr. \& Zuloaga. One species was described after the creation of the genus: $P$. colombiensis Davidse \& Zuloaga (Zuloaga and Davidse, 1999). Parodiolyra was deemed to be very close to Raddiella Swallen (Zuloaga and Judziewicz, 1991), and this relationship has been confirmed by molecular phylogenies of the group (Oliveira, 2006).

All Parodiolyra species are perennial, growing in erect clumps, sometimes slightly decumbent or recurved, with rarely branched culms and symmetrical, lanceolate to broadly oval leaf blades (Oliveira and Longhi-Wagner, 
2001). Inflorescences are arranged in terminal panicles, with the lower branches having male spikelets only, and the upper branches having female spikelets only, and these are characters which are widely used to characterise the genus (Oliveira, 2001). In addition, male and female spikelets are conspicuously dimorphic, the female being larger, with filiform pedicels disarticulated below the two glumes, which are absent in the male spikelets (Oliveira, 2001).

Parodiolyra is regarded as very heterogeneous both on vegetative characters and morphology of the spikelets, the latter containing very useful characters that clearly delimit the species, as can be inferred in the identification keys shown by Soderstrom and Zuloaga (1989), Zuloaga and Davidse (1999) and Oliveira (2001). However, these structures are not always available in the collections found in herbaria or in the field, making it necessary to search for other tools to aid in identification - for example, leaf anatomy.

Only two species of this genus occur in Eastern Brazil, and they were cited for the state of Bahia by Oliveira (2001). Parodiolyra micrantha (Figures 1-2) is widely distributed in Neotropical forests (Oliveira and LonghiWagner 2001), being one of the most common species of herbaceous bamboos across the state. The species possess great ecological amplitude, being found at the edges of rainforests, riparian forests, marshes and even in the highland areas of the Chapada Diamantina (Oliveira, 2001). On the other hand, P. ramosissima (Figures 3-4) is endemic to Bahia, being found predominantly in low-lying coastal forests and sand dune vegetation of the southern region of the state, in the sand dunes of Salvador and in the humid forests of the Serra da Jibóia (Oliveira 2001).

As common in other Poaceae, bamboos have similar characters of leaf anatomy, such as fusiform and arm cells in the chlorenchyma, not radiate mesophyll and two-celled trichomes of the Panicum type (GPWG 2001). However, the effectiveness of these and other characters for the taxonomy of the group has been little evaluated, especially with regard to herbaceous groups. The available literature indicates that these characters can vary little within a genus, as indicated in Oliveira et al. (2008a) for Raddia Bertol., or they can vary considerably and even help in specific delimitation, as for instance within Pariana Aubl. in Eastern Brazil (Oliveira et al., 2008b).

The data analysed here represent the first formal description of leaf anatomy of members of Parodiolyra, contributing to increase the knowledge about the group. Our main objective was to examine the leaf anatomy of representatives of this genus occurring in forests of Eastern Brazil, based on samples collected in the state of Bahia, in order to evaluate the efficiency of leaf microscopic characters for specific delimitation in the group.

\section{Materials and methods}

We analysed the second leaf blade above the inflorescence on samples of Parodiolyra micrantha, from Salvador (L. Noblick 1625), Igrapiúna (R.P. Oliveira et al. 1368) and Lençóis (R.P. Oliveira et al.139), and samples of $P$. ramosissima collected at Itacaré ( $R$.P. Oliveira et al. 688), Salvador (Grupo da Oceplan s/n, ALCB 19873) and Camamú (L.A. Mattos-Silva 4387). The voucher specimens are deposited at the Herbarium of the Universidade Estadual de Feira de Santana (HUEFS), except the specimen collected by the Grupo da Oceplan s.n., which is deposited at the Herbarium of the Universidade Federal da Bahia (ALCB). The leaf blades were prepared in transversal and paradermal sections to be observed under an optical microscope. We used fresh material preserved in a $70 \%$ ethanol solution whenever possible, but the majority of the material used was prepared from herbarium specimens, rehydrated with boiling water and glycerin (9:1), and preserved in a $70 \%$ ethanol solution (Johansen, 1940).

For the anatomical analysis of both transversal and paradermal sections, we used the middle portion of the second leaf blade below the inflorescence. The paradermal sections were obtained by hand with a blade, or through epidermis dissociation by Jeffrey's Mixture (chromic acid and nitric acid at 10\%) (Johansen, 1940). In both procedures the samples were stained with a $1 \%$ solution of hydroalcoholic safranin. To obtain the cross sections, the material was embedded in paraffin according to Sass (1940) and sectioned in a rotatory microtome. The paradermal and transversal sections were mounted using glycerin jelly and Entellan respectively (Kraus and Arduin, 1997).

All slides prepared were observed, measured and photographed in an optical microscope. To verify that
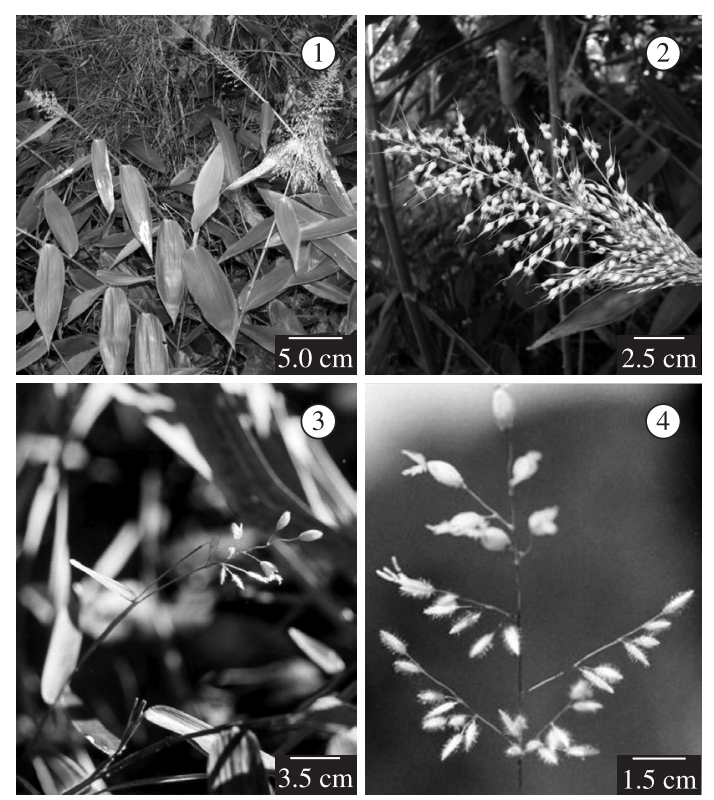

Figures 1-4. Representatives of Parodiolyra Soderstr. \& Zuloaga used in this study. 1-2: P. micrantha (Kunth) Zuloaga \& Davidse: 1) Habit; 2) Inflorescences, the left one a young inflorescence (Oliveira et al. 239 (HUEFS); 3-4) Inflorescence of $P$. ramosissima (Trin.) Soderstr. \& Zuloaga: (M.M. Silva et al. 369 (HUEFS). Bars $1=5 \mathrm{~cm}$; $2=2,5 \mathrm{~cm} ; 3=3,5 \mathrm{~cm} ; 4=1,5 \mathrm{~cm}$. 
microtypes observed in both species were significantly different, measurements of epidermal cells and fusiform cells size were compared using the $t$-test, previously tested for normality using the Kolmogorov-Smirnov test, using GraphPad Instat versão 3.0 (Motulsky, 2003). Only the measurements of epidermal cells from the abaxial surface of $P$. ramosissima were not normal, and thus a non-parametric $t$-test was used in order to investigate possible differences between the two surfaces of the leaf.

\section{Results and discussion}

In a paradermal view, the epidermal cells of both species are long and interspaced by short cells (Figure 5), arranged in longitudinal rows and divided into costal and intercostal zones (Figure 5), as described by GPWG (2001) for other grasses. The short epidermal cells may be silicified and crenate in the intercostal zones (Figures 6, 9), and cruciform in the costal zones (Figure 7). The silica absorbed by plant roots is translocated and deposited in tissues of many plants, particularly grasses, and usually this can be related to the environment in which they grow (Lanning and Eleuterius, 1983).

Long cells of the epidermis of both species analyzed presented conspicuous papillae at abaxial surface (Figures 6-7, 12-13). In Parodiolyra micrantha, lobed papillae were also observed in addition to simple papillae, numbering one to three per cell but predominantly two, whereas in P. ramosissima there are one to two papillae per cell, predominantly only one. This difference between them emphasizes that the morphology and distribution of these papillae are important taxonomic characters in bamboos, as pointed out by Oliveira et al. (2008a,b) and Vieira et al. (2002) for other genera of Olyreae, and Clark et al. (1989) for woody bamboos.

The stomatal complex of Parodiolyra consists of two dumbbell-shaped occlusive cells, while the subsidiary cells have a triangular shape (Figure 10) typical of grasses (Metcalfe 1960; Alquini et al., 2006). Both species are amphistomatic, having fewer stomata on the adaxial surface. This was also observed by Vieira et al. (2002) in leaf blades of Raddia brasiliensis Bertol., while Oliveira et al. (2008a) indicate that this pattern occur in only one ( $R$. porto $i$ Kuhlm.) of the nine species of this genus, the remaining species being hypostomatic.

Short and silicified unicellular trichomes ("prickle-hairs") were observed on both leaf surfaces in Parodiolyra micrantha, along the midrib and costal and / or intercostal areas of the two faces of the epidermis, being more numerous in the abaxial surface. In $P$. ramosissima these trichomes were observed only in the abaxial surface (Figures 7, 11-12). These prickle-hairs occur in several other herbaceous bamboos, as in Pariana (Oliveira et al., 2008a) and Raddia (Oliveira et al., 2008b). We also observed bicellular trichomes (microhairs) (Figure 13), which were found in both species and on both surfaces, with higher density on the abaxial surface.

The leaf epidermis is uniseriate in cross-section (Figures 14-21), with cells of the adaxial surface being larger than the cells of the abaxial surface, as evidenced earlier by Vieira et al. (2002) and Oliveira et al. (2008a) for other Olyreae. This result was statistically significant between the two species analysed, with the difference more pronounced in $P$. ramosissima (adaxial surface with 4-7 microns and abaxial with 2-4 microns, standard deviation: $1, \mathrm{p}<0.0001$ ), as compared to $P$. micrantha (adaxial surface with 2-6 microns and abaxial with 2-5 microns, standard deviation: $1, \mathrm{p}=0.002$ ). Both species were similar in possessing groups of buliforms cells, which were only found on the adaxial epidermis of the two species, being located between the vascular bundles along the entire length of the leaf blade (Figures 14-17, 20-21).

The chlorenchyma on both species is formed by arm and fusiform cells associated with vascular bundles of first and second degrees. The arm cells are positioned above and below the fusiform ones, having one or two layers on both surfaces, with the deepest invaginations found in the adaxial surface (Figures 16, 20). The size of the fusiform cells was statistically different when the two species were compared $(\mathrm{p}=0.0012)$, with the cells of Parodiolyra micrantha (126-224 microns, arithmetic average: 181, standard deviation: 28) larger in length than those $P$. ramosissima (84-210 microns, arithmetic average: 153 , standard deviation: 37$)$. A pattern of length differences for this type of cell was observed in the species analyzed, where the first fusiform cell after the midrib was smaller than the second, and the second smaller than the third. Thereafter, the cell length did not have further significant differences.

The length and shape of these fusoid cells can vary among species of other Olyreae, as in Raddia, Piresia Swallen and Olyra L. (Oliveira et al., 2008b). According to these authors there are some hypotheses about the function of these fusoid cells, but none of them tested so far. The same may be related to $\mathrm{CO}_{2}$ capture and reserve and diffusion between the cells of the chlorenchyma and the two faces of the epidermis.

The vascular bundles are collateral in both species investigated, being surrounded by two-layered sheath. The inner one with sclerified thick-walled cells and the outer one with parenchyma cells (Figure 17, 21). The midrib region is well defined, and in Parodiolyra micrantha it is flat on the abaxial surface and convex on the adaxial surface, with a middle vascular bundle in a sub-central position and usually three adjacent bundles of smaller size (Figure 14). However in P. ramosissima the midrib region is convex and prominent on both surfaces, with the middle bundle shifted to the abaxial surface and two smaller adjacent bundles (Figure 18). Also in the midrib region, there are four to five layers of ground parenchyma cells in P. micrantha, and from five to six cell layers of this tissue found in P. ramosissima. 

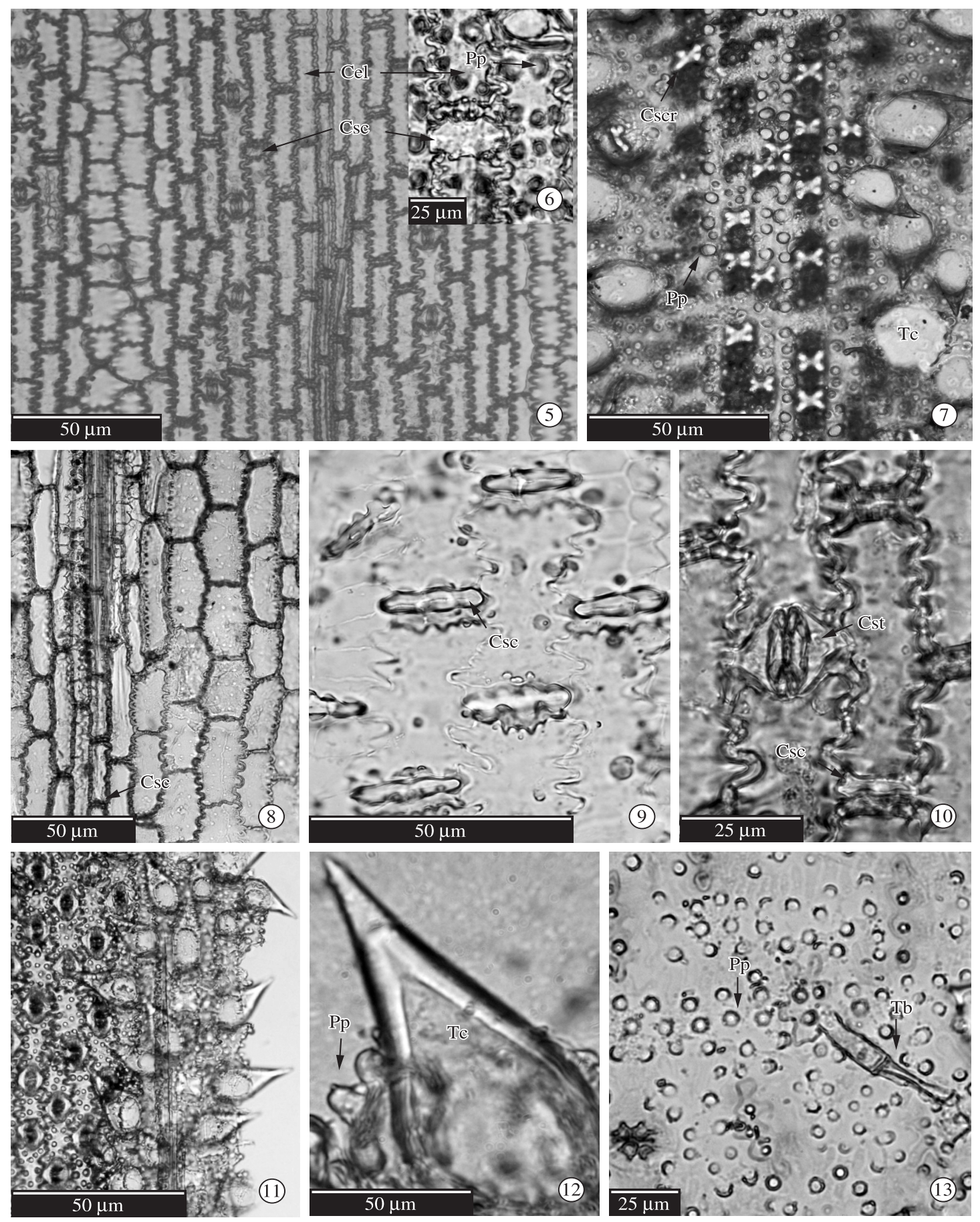

Figures 5-13. Paradermal sections of leaves; 5-8) Parodiolyra micrantha (Kunth) Zuloaga \& Davidse: 5) General view of the adaxial epidermis; 6) Detail of a silicified crenate cell in the intercostal zone; 7) Detail of silicified cruciform cell in the costal zone, with papillae and short trichomes; 8) General view of the abaxial epidermis. 9-13) P. ramosissima (Trin.) Soderstr. \& Zuloaga; 9) General view of the adaxial epidermis with detail of silicified crenate cells; 10) Detail of stoma with club-shaped guard cells and triangular subsidiary cells; 11) Distribution of the unicellular trichomes; 12) Detail of a unicellular trichome; 13) Abaxial epidermis with bicellular trichome. Acronyms: Cel - Csc - silicified crenate cells; Cscr - silicified cruciforme cells; Cst - triangular subsidiary cells; $\mathrm{Pp}$ - papillae; $\mathrm{Tb}$ - bicellular tector trichome; $\mathrm{Tc}$ - short unicellular trichome. Bars 5 , 7-9, 11-12 = $50 \mu \mathrm{m}$; Bars 6, 10, $13=25 \mu \mathrm{m}$. 

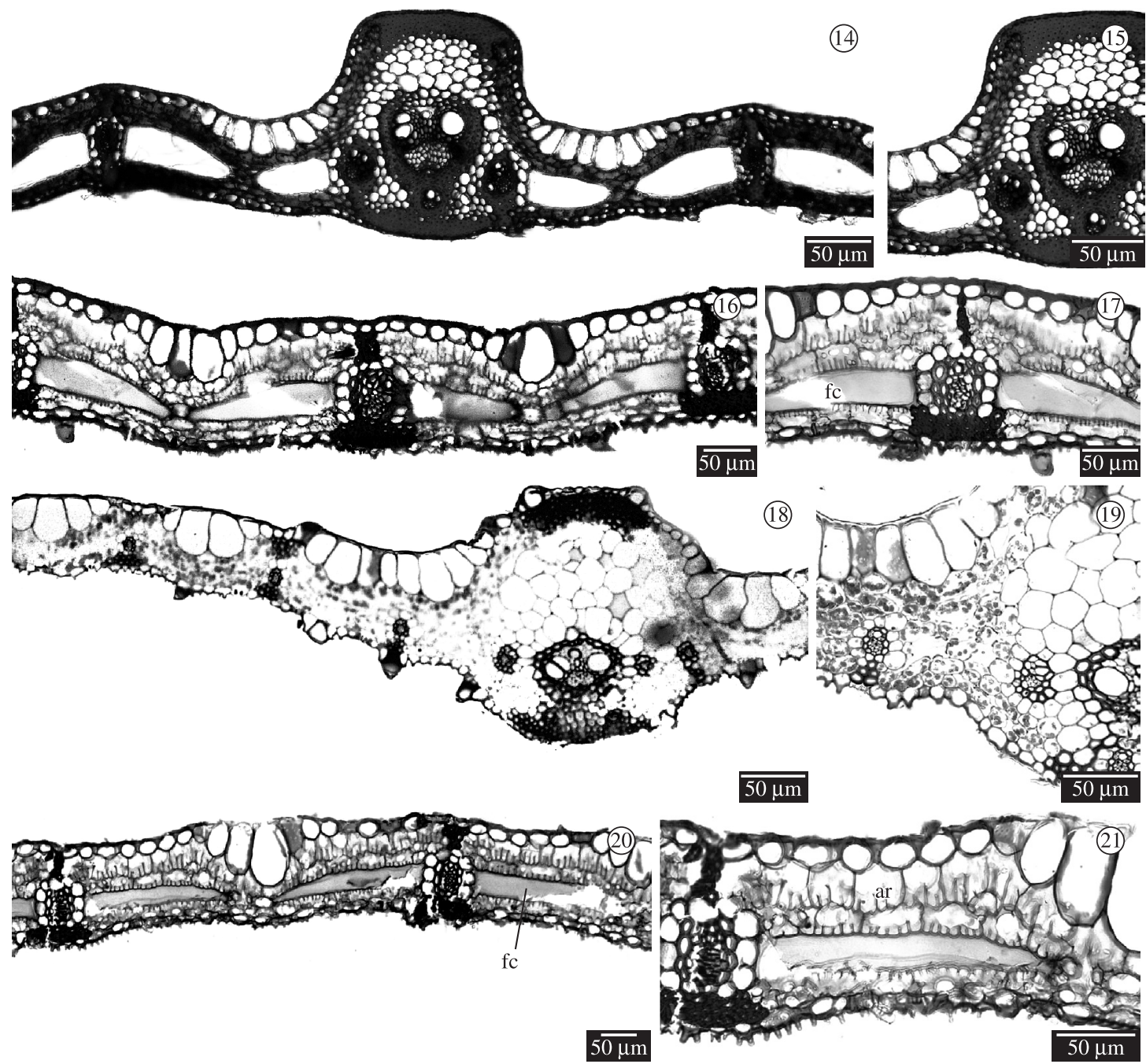

Figures 14-21. Transversal sections of leaf blades; 14-17) Parodiolyra micrantha (Kunth) Zuloaga \& Davidse: 14) Midrib with three adjacent vascular bundles; 15) Detail of the midrib with a lateral vascular bundle; 16) General view of the mesophyll with distribution of fusiform cells; 17) Detail of the vascular bundle and mesophyll with arm cells; 18-21) P. ramosissima (Trin.) Soderstr. \& Zuloaga. 18) Midrib with adjacent vascular bundles; 19) Detail of the midrib; 20) General view of the mesophyll with distribution of fusiform cells; 21) Detail of the vascular bundle and mesophyll with arm cells. Acronyms: fc - fusiform cells; ar - arm cells; Bars $=50 \mu \mathrm{m}$.

\section{Conclusions}

The anatomical structures observed in Parodiolyra micrantha and $P$. ramossisma shows that the characters: shape of the midrib; position of the middle vascular bundle and number of adjacent vascular bundles; number of parenchyma layers associated to the middle vascular bundle; epidermal cell size; distribution of unicellular trichomes; and morphology and distribution of papillae, are useful characters that can be used to delimit the two species. This work reinforces the usefulness of anatomical investigations as instruments for specific delimitation in the tribe Olyreae, and also contributes to expand the knowledge on the leaf anatomy of forest species of Poaceae.
Acknowledgements - We thank the Universidade Federal da Bahia - UFBA, Universidade Estadual de Feira de Santana - UEFS and Faculdade de Tecnologia e Ciências - FTC for the infrastructure made available for the execution of this work; the Fundação de Amparo à Pesquisa do Estado da Bahia - FAPESB and Conselho Nacional de Desenvolvimento Científico e Tecnológico-CNPq for the financial support (grants FAPESB 0218/2008 and 083/2010; CNPq 478901/2008-9 and 562349/2010-3); and to Wagner B. da Hora for his help with the editing of the pictures.

\section{References}

ALQUINI, Y., BONA, C., BOEGER, MRT. and BARROS, CF., 2006. Epiderme. In APEZATTO-DA-GLÓRIA, B. and CARMELLO-GUERREIRO, SM. (Eds). Anatomia vegetal. Viçosa: Ed. UFV. p. 87-108. 
CLARK, LG., DAVIDSE, G. and ELLIS, RP., 1989. Natural hybridization in bamboos: evidence from Chusquea sect. Swallenochloa (Poaceae: Bambusoideae). National Geographic Magazine, vol. 5, no. 10, p. 459-476.

Grass Phylogeny Working Group - GPWG., 2001. Phylogeny and subfamilial classification of the grasses (Poaceae). Annals of the Missouri Botanical Garden, vol. 88, p. 373-457. http:// dx.doi.org/10.2307/3298585

JOHANSEN, DA., 1940. Plant microthechine. New York: McGraw-Hill Book Co. Inc.

KRAUS, JE. and ARDUIN, M., 1997. Manual básico de métodos em morfologia vegetal. Seropédica: EDUR. 198 p.

LANNING, FC. and ELEUTERIUS, LN., 1983. Silica and ash in tissues of some coastal plants. Annals of Botany, vol. 51, p. 835-850.

METCALFE, R., 1960. Anatomy of the Monocotyledons. Oxford: Claredon Press.

MOTULSKY, H., 2003. Graph Pad In Stat: The InStat guide to choosing and interpreting statistical tests. version 3.0. GraphPad Software, Inc.

OLIVEIRA, RP., 2001. A tribo Olyreae (Poaceae: Bambusoideae) no Estado da Bahia, Brasil. Feira de Santana: Universidade Estadual de Feira de Santana. Dissertação de Mestrado em Botânica.

OLIVEIRA, RP., 2006. Estudos taxonômicos, filogenéticos e biossistemáticos em Raddia Bertol. (Poaceae: Bambusoideae: Olyreae). Feira de Santana: Universidade Estadual de Feira de Santana. Tese de Doutorado.

OLIVEIRA, RP. and LONGHI-WAGNER, HM., 2001. Parodiolyra Soderstr. \& Zuloaga. In WANDERLEY, MGL., SHEPHERD, GJ. and GIULIETTI, AM. (Orgs.). Flora Fanerogâmica do Estado de São Paulo. São Paulo: Hucitec. vol. 1: Poaceae, p. 47-48.

OLIVEIRA, RP., LONGHI-WAGNER, HM. and LEITE, KRB., 2008a. A contribuição da anatomia foliar para a taxonomia de Raddia Bertol. (Poaceae: bambusoideae). Acta Botanica Brasilica, vol. 22, no. 1, p. 1-19. http://dx.doi.org/10.1590/ S0102-33062008000100002

OLIVEIRA, RP., LONGHI-WAGNER, HM., LEITE, KRB. and HOLLOWELL, VC., 2008b. Pariana multiflora (Poaceae: Bambusoideae: Olyreae): a new species from Brazil and notes on the leaf anatomy of this genus in Eastern Coast Brazil. Systematic Botany, vol. 33, no. 2, p. 262-266. http://dx.doi. org/10.1600/036364408784571617

SASS, J., 1940. Elements of Botanical Microtechnique. New York and London. 222 p.

SODERSTROM, TR. and ZULOAGA, FO., 1989. A revision of the genus Olyra and the new segregate genus Parodiolyra (Poaceae: Bambusoideae: Olyreae). Smithsonian contributions to botany, vol. 69 , p. 1-79.

VIEIRA, RC., GOMES, DMS., SARAHYBA, LS. and ARRUDA, RCO., 2002. Leaf anatomy of three herbaceous bamboo species. Brazilian Journal of Biology, vol. 62, p. 907-922. http://dx.doi. org/10.1590/S1519-69842002000500021

ZULOAGA, FO. and DAVIDSE, G., 1999. A new species and a new combination in the genus Parodiolyra (Poaceae: Bambusoideae: Olyreae). Novon, vol. 9, no. 4, p. 587-591. http:// dx.doi.org/10.2307/3392172

ZULOAGA, FO. and JUDZIEWICZ, EJL., 1991. A revision of Raddiella (Poaceae: Bambusoideae: Olyreae). Annals of the Missouri Botanical Garden, vol. 78, p. 928-941. http://dx.doi. org/10.2307/2399734 